\title{
Radiological and Clinical Manifestations of Metastatic Pulmonary Calcification in a Patient with Parathyroid Hyperplasia
}

\author{
Paratiroid Hiperplazili Olguda Metastatik Pulmoner Kalsifikasyonun Radyolojik ve \\ Klinik Bulguları ile Birlikte Değerlendirilmesi
}

\author{
(1) Aslı Tanrıvermiş Sayıt, (1) Muzaffer Elmalı, (D Dilek Sağlam \\ Ondokuz Mayıs University Faculty of Medicine, Department of Radiology, Samsun, Turkey
}

\begin{abstract}
Metastatic pulmonary calcification (MPC) is the deposition of calcium salts in the walls of the alveoli and small blood vessels in normal tissue. MPC may be associated with end-stage renal disease, primary and secondary hyperparathyroidism, diffuse skeletal malignancy, intravenous calcium therapy, massive osteolysis from metastases, and multiple myeloma. We present a case of a 53-year-old-man with end-stage renal disease and primary hyperparathyroidism presented with hip and chest pain. Computed tomography of the chest revealed multiple, ground-glass opacities associated with poorly defined centrilobular nodules and numerous calcific nodules, consistent with MPC.
\end{abstract}

Keywords: Computed tomography, hyperparathyroidism, metastatic pulmonary calcification, parathyroid adenoma
Öz

Metastatik pulmoner kalsifikasyon (MPK) alveol duvarlarında ve normal dokuların küçük kan damarlarında kalsiyum tuzlarının birikimidir. MPK, son dönem böbrek hastalığı, primer ve sekonder hiperparatiroidi, diffüz iskelet malignitesi, intravenöz kalsiyum terapisi, metastaza bağlı masif osteoliz ve multipl miyelom gibi hastalıklarda ortaya çıkabilir. Biz burada son dönem böbrek hastalığı ve primer hiperparatiroidi ile birlikte kalça ve göğüs ağrısı bulunan 53 yaşında erkek hastanın bilgisayarlı tomografide izlenen multipl, buzlu cam dansitesinde sentrilobüler nodüller ve kalsifik nodüller ile karakterize MPK görünümünü ilgili literatür eşliğinde sunmayı amaçladık.

Anahtar Sözcükler: Bilgisayarlı tomografi, hiperparatiroidi, metastatic pulmoner kalsifikasyon, paratiroid adenoma

\section{Introduction}

Metastatic pulmonary calcification (MPC) is a deposition of calcium salts in normal alveoli, interstitium, and bronchovascular tissue (1). MPC may be associated with end-stage renal disease (ESRD) and other disorders, such as hyperparathyroidism, diffuse skeletal malignancy, massive osteolysis from metastases, and multiple myeloma as well as intravenous calcium therapy $(1,2)$. Chest X-rays can be used for the diagnosis of MPC, however, the findings are often normal since they are not sensitive. Computed tomography (CT) is a highly sensitive and useful imaging technique for the diagnosis of MPC. Calcifications can be detected easily. Also, CT shows calcification of the trachea, bronchi, blood vessel walls, and myocardial calcifications and other accompanying pathologies (1). We present the case of MPC in a patient with ESRD who presented with femoral neck fracture, as well as a brief literature review, including clinical and imaging findings.

\section{Case}

A 53-year-old male presented to the hospital with the complaints of left hip pain and chest pain for the preceding month. Anterior posterior pelvic and lateral hip X-rays were taken and showed left femur neck fracture. Physical
Address for Correspondence/Yazışma Adresi: Aslı Tanrıvermiş Sayıt Ondokuz Mayıs University Faculty of Medicine, Department of Radiology, Samsun, Turkey Phone: +90 5324949082 E-mail: draslitanrivermissayit@gmail.com ORCID ID: orcid.org/0000-0003-2861-156X Received/Geliş Tarihi: 23 December 2017 Accepted/Kabul Tarihi: 23 March 2018
${ }^{\circ}$ Copyright 2018 by The Medical Bulletin of University of Health Sciences Haseki Training and Research Hospital
The Medical Bulletin of Haseki published by Galenos Yayinevi.

${ }^{\circledR}$ Telif Hakkı 2018 Sağlık Bilimleri Üniversitesi Haseki Eğitim ve Araştırma Hastanesi Haseki Tıp Bülteni, Galenos Yayınevi tarafından basıımıştır. 
exam was grossly unremarkable except for left hip pain, and vital signs were stable. He had a history of 70 pack/ year smoking and chronic renal failure. He underwent hemodialysis three times per week for 16 years. The following serum levels were recorded (normal values in parentheses): creatinine: $8.64 \mathrm{mg} / \mathrm{dL}(0.40-1.40)$, calcium: $10 \mathrm{mg} / \mathrm{dL}$ (9.0-10.2), phosphor: $4.58 \mathrm{mg} / \mathrm{dL}$ (2.3-4.7), and parathyroid hormone: $3.259 \mathrm{pg} / \mathrm{mL}(<50 \mathrm{pg} / \mathrm{mL})$. Cervical ultrasonography (US) (Toshiba Medical Systems Corporation, Otawara, Japan) was performed due to the high level of parathyroid hormone. On US, there was homogeneous, hypoechoic well-defined $2-\mathrm{cm}$ diameter nodule adjacent to the lower pole of the left thyroid lobe. A technetium-99m methoxy-isobutyl-isonitrile (99mTc$\mathrm{MIBI}$ ) scan was performed for detection of the parathyroid adenoma, and 99mTc-MIBI accumulation was detected in the adjacent structures of the lower pole of the left thyroid lobe. Chest X-ray revealed numerous diffuse confluent nodular opacities with poorly defined margins (Figure 1). Chest CT was performed without history of dust exposure and malignancy. Chest CT revealed groundglass opacities associated with poorly defined centrilobular nodules and numerous calcific nodules (Figure 2a, b). Also, circumferential calcification of the trachea, bronchi, and bronchioles was detected. A homogeneous, hyperdense, well-defined 2-cm-diameter nodule adjacent to the lower pole of the left thyroid lobe was detected (Figure 3). Osteoporosis and lytic lesions were seen in all of the bony structures of the thorax. MPC was considered in the differential diagnosis of pulmonary calcification. Imaging findings and medical history were compatible with MPC. The patient underwent parathyroidectomy. Histolopathological examination demonstrated parathyroid hyperplasia. The creatinine level was $2.35 \mathrm{mg} / \mathrm{dL}$ (0.40-1.40) and calcium

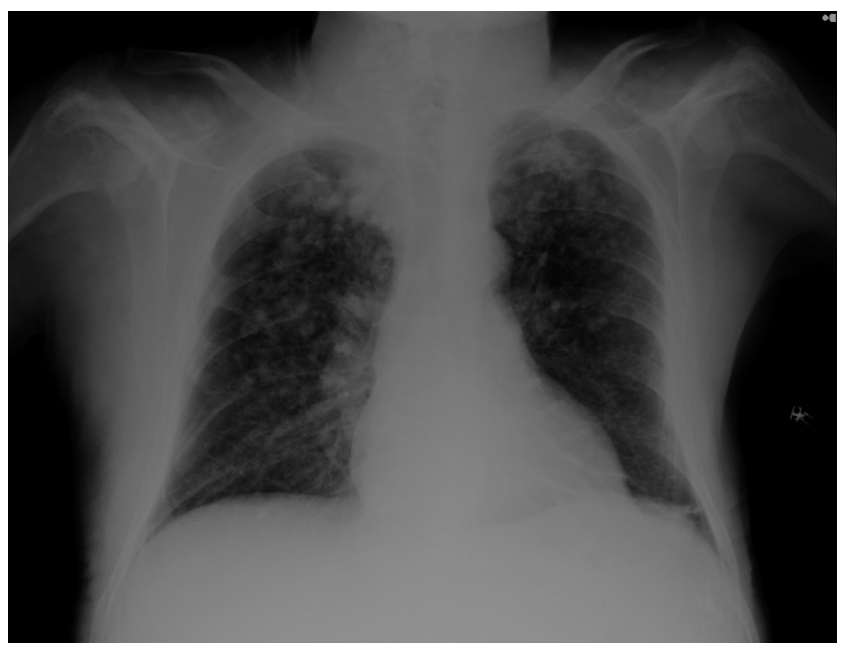

Figure 1. Chest X-ray shows numerous diffuse confluent nodular opacities with poorly defined margins, predominantly in the upper zone

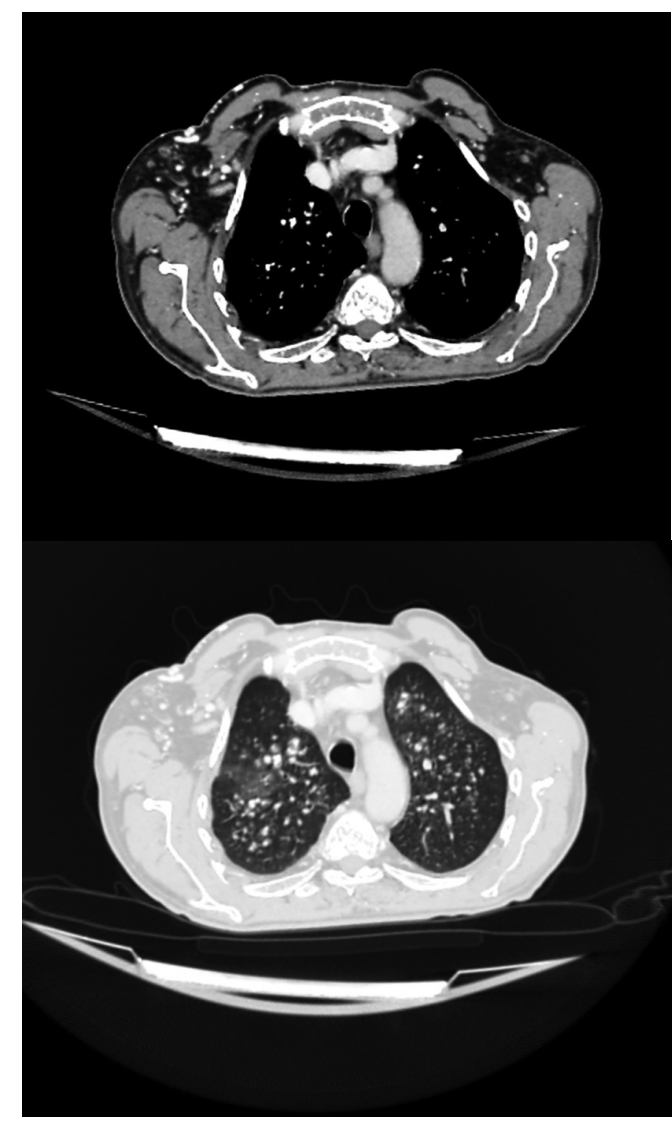

Figure 2a, b. Axial contrast enhanced computed tomography with (a) mediastinal and (b) parankimal windows reveal groundglass opacities associated with poorly defined centrilobular nodules and numerous calcific nodules

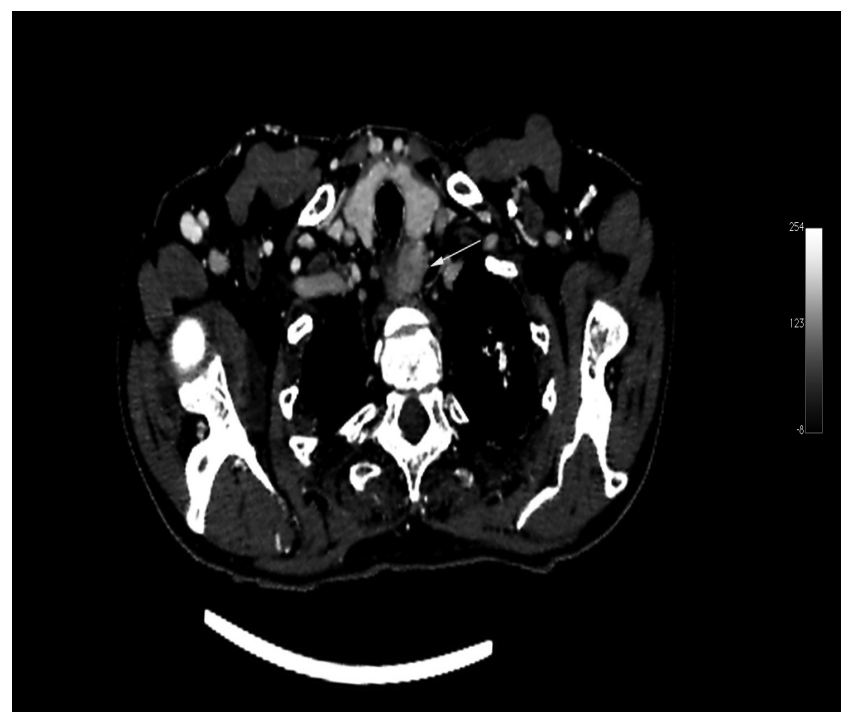

Figure 3. Axial contrast enhanced computed tomography shows homogeneous, hyperdense, well-defined 2-cm-diameter nodules (arrow) adjacent to the lower pole of the left thyroid lobe 
level was $9.9 \mathrm{mg} / \mathrm{dL}$ (9.0-10.2) four months after surgery. Informed consent was obtained from the patient.

\section{Discussion}

Metastatic calcification is a deposition of calcium salts in normal tissue. It occurs most commonly in the lungs, kidneys, gastric mucosa, heart, and vessel walls (3). MPC can be caused by chronically elevated serum calciumphosphorus levels, as in chronic renal failure, primary and secondary hyperparathyroidism, hypervitaminosis $D$, milkalkali syndrome, or diffuse myelomatosis $(2,3)$.

In addition, MPC is a complication of ESR failure and its treatment (1). The process is often undiagnosed in antemortem, however, commonly at autopsy in patients with renal failure. Most patients are asymptomatic, although some patients may present with fulminant respiratory failure and early death. Also, dyspnea and chronic, non-productive cough can be seen (4). Calcium salts often accumulate in alveolar walls and less often in bronchiole walls, pulmonary arteries, and veins (1). Apical segments are more affected than basal segments. The degree of respiratory distress usually is not associated with the degree of macroscopic calcification. Patients with extensive calcification may be asymptomatic. Also, mild calcification can cause severe respiratory failure (4).

Small calcifications cannot always be seen clearly on chest X-rays. Therefore, chest X-rays are often normal in patients with MPC (4). However, sometimes confluent or patchy airspace opacities may be seen on chest $X$-rays. This appearance can be simulated pneumonia, or infarction or pulmonary edema (5). Additionally, on chest X-ray, diffuse interstitial patterns or discrete or confluent calcified nodules can be seen in patients with MPC (1).

CT is very sensitive for the detection of small calcifications. Thus, it is the most preferred imaging modality in the diagnosis of MPC (3). Numerous patterns have been described on CT. These are multiple diffuse calcified nodules that are either distributed throughout the whole lung or show a predilection for the apices, diffuse or patchy areas of ground-glass opacity or consolidation, and confluent high-attenuation parenchymal consolidation. In addition, calcifications can be seen in the bronchial wall, myocardium, and the vessels of the chest wall (4). In our case, CT demonstrated multiple symmetrical, centrilobular, calcified nodules and patchy areas of ground-glass opacity throughout both lungs, especially the upper and middle lobes. Additionally, calcification was seen in the bronchial and tracheal walls.

The main differential diagnosis for MPC is dystrophic calcifications. Dystrophic calcification is the deposition of calcium salts in dead cells or tissue damaged by infections (tuberculosis, fungal infections, and chickenpox pneumonitis), silicosis, sarcoidosis, metastatic tumor, rheumatic mitral stenosis, microlithiasis, and broncholithiasis (5). Parenchymal calcified nodules are located mainly in the subpleural areas of the middle and lower zones in diffuse parenchymal amyloidosis. Also, hilar lymphadenopathy, interlobular septal thickening, consolidation, and ground-glass opacities can be seen in amyloidosis. The calcified pulmonary nodules in alveolar microlithiasis are smaller and typically seen in the lower zones and the paracardiac regions. Besides, apical bullae and subpleural cysts may be seen in alveolar microlithiasis (4). Miliary tuberculosis show multiple tiny discrete nodules randomly distributed in both lungs. Rarely, nodules can be calcified (4). Metastatic calcification tends to involve mainly the upper lung zones. Calcifications can also be seen in the myocardium, walls of the bronchioles, and the vessels of the chest wall (4). In our patient, pulmonary calcifications occurred due to hypercalcemia related to primary hyperparathyroidism and chronic renal failure. There are many reported cases of MPC related to chronic renal insufficiency and secondary hyperparathyroidism in the literature. However, cases of MPC related to primary hyperparathyroidism are limited in the literature (6).

Pulmonary calcification associated with renal failure is potentially reversible, and may resolve after parathyroidectomy, renal transplant, or adequate dialysis. (4). However, irreversible lung damage and respiratory failure can develop in untreated patients (3).

Chest $\mathrm{CT}$ is a valuable imaging modality in the diagnosis of pulmonary calcifications. It is very sensitive for identifying renal calcifications. Also, other mediastinal pathologies, such as tracheobronchial and myocardial calcifications, can be detected with CT as in our case. Primarily, MPC should be considered in differential diagnosis with these imaging findings. Diagnosis of MPC prevents unnecessary biopsies. Respiratory failure and irreversible lung damage can be avoided with early treatment.

\section{Authorship Contributions}

Concept: A.T.S, M.E. Design: A.T.S. Data Collection or Processing: A.T.S. Analysis or Interpretation: A.T.S, D.S. Literature Search: A.T.S. Writing: A.T.S

Conflict of Interest: No conflict of interest was declared by the authors.

Financial Disclosure: The authors declared that this study received no financial support.

\section{References}

1. Patel G, Yepes-Hurtado A, Huizar I. Metastatic Pulmonary Calcification An Uncommon Clinical Condition in End-Stage Renal Disease. The Southwest Respiratory and Critical Care Chronicles 2014;2:29-33.

2. Hochhegger B, Marchiori E, Soares Souza A Jr, Soares Souza L, Palermo L. MRI and CT findings of metastatic pulmonary calcification. Br J Radiol 2012;85:69-72. 
3. Surani SR, Surani S, Khimani A, Varon J. Metastatic pulmonary calcification in multiple myeloma in a 45-year-old man. Case Rep Pulmonol 2013;2013:341872.

4. Alkan O, Tokmak N, Demir S, Yildirim T. Metastatic pulmonary calcification in a patient with chronic renal failure. J Radiol Case Rep 2009;3:14-7.
5. Murris-Espin M, Lacassagne L, Didier A, et al. Metastatic pulmonary calcification after renal transplantation. Eur Respir J 1997;10:1925-7.

6. Yoon EJ, Kim DH, Yoon SH, Suk EH. Rapid Progression of Metastatic Pulmonary Calcification and Alveolar Hemorrhage in a Patient with Chronic Renal Failure and Primary Hyperparathyroidism. J Korean Soc Radiol 2013;68:473-7. 